\title{
Isolation and antimicrobial resistance of coagulase-negative staphylococci recovered from healthy tortoises in Minas Gerais, Brazil
}

\author{
Jordana Almeida Santana ${ }^{1}$ (i) Brendhal Almeida Silva ${ }^{1}$ (i) Nathalia Abreu Borges Trevizani ${ }^{2}$ (a) \\ Angélica Maria Araújo e Souza $^{2}$ (D) Grécia Mikhaela Nunes de Lima ${ }^{2}$ (I) \\ Nathalia Rodrigues Martins Furtado ${ }^{2}$ (i) Francisco Carlos Faria Lobato ${ }^{1}$ (i) \\ Rodrigo Otávio Silveira Silva ${ }^{1^{*}}$ (1)
}

${ }_{1}^{1}$ Universidade Federal de Minas Gerais(UFMG), 31270-901,Belo Horizonte, MG, Brasil. E-mail: rodrigo.otaviosilva@gmail.com..'Corresponding author. ${ }^{2}$ Waita Instituto de Pesquisa e Conservação, Belo Horizonte, MG, Brasil.

\begin{abstract}
In the last few decades, there has been a global increase in the adoption of reptiles as companion animals, mainly turtles and tortoises. Considering the popularity of reptiles as pets in Brazil, and a notable lack of data about potentially pathogenic staphylococci in these animals, this study isolated and evaluate the antimicrobial susceptibility of staphylococcal species from healthy tortoises (Chelonoidis carbonaria) in Brazil. During a 12-month period (February 2019 to February 2020), cloacal swabs from 66 healthy tortoises were collected at the Wild Animals Screening Center in Belo Horizonte, Minas Gerais, Brazil. The swabs were plated onto mannitol salt agar for staphylococci isolation, and species identification was performed using MALDI-TOF MS. Antimicrobial susceptibility was investigated using the disk diffusion method, and the presence of the mecA gene was investigated by PCR to detect methicillin resistance. Of the tested animals, $72.7 \%$ were positive for staphylococcal isolation. All isolates were coagulase-negative staphylococci (CoNS), and Staphylococcus sciuri (81.3\%), and S. xylosus (12.5\%) were the most frequently isolated species. The majority of the isolates (56\%) were resistant to at least one antimicrobial agent. A high frequency of resistance was observed for penicillin (35.5\%) and tetracycline (29.1\%). All strains were susceptible to cefoxitin, chloramphenicol, ciprofloxacin, erythromycin, and gentamicin. All isolates were negative for the mecA gene. The present work suggests that healthy tortoises are mainly colonized by CoNS, especially S. sciuri. Half of the isolates were resistant to at least one antimicrobial, raising questions regarding the possible role of these animals as reservoirs of antimicrobial resistance genes.
\end{abstract} Key words: reptiles, coagulase-negative staphylococci, S. sciuri, S. xylosus, Chelonoidis carbonaria.

Isolamento e resistência aos antimicrobianos de estafilococos coagulase negativos recuperados de jabutis saúdáveis em Minas Gerais, Brasil

RESUMO: Nas últimas décadas, houve um aumento global na adoção de répteis como animais de companhia, principalmente tartarugas e jabutis. Considerando a popularidade dos répteis como animais de estimação no Brasil e a notável falta de dados sobre estafilococos potencialmente patogênicos nesses animais, o objetivo deste estudo foi isolar e avaliar a susceptibilidade antimicrobiana de espécies estafilocócicas de jabutis (Chelonoidis carbonaria) saudáveis no Brasil. Durante um período de 12 meses (fevereiro de 2019 a fevereiro de 2020), suabes cloacais de 66 jabutis saudáveis foram coletados no Centro de Triagem de Animais Silvestres em Belo Horizonte, Minas Gerais, Brasil. Os suabes foram plaqueados em ágar manitol salgado para isolamento de estafilococos e a identificação das espécies foi realizada usando MALDI-TOF MS. A susceptibilidade aos antimicrobianos foi investigada pelo método de difusão em disco, e a presença do gene mecA foi investigada por PCR para detectar resistência à meticilina. Dos animais testados, 72,7\% foram positivos para o isolamento estafilocócico. Todos os isolados eram estafilococos coagulase-negativos (CoNS), sendo Staphylococcus sciuri (81,3\%) e S. xylosus (12,5\%) as espécies mais frequentemente isoladas. A maioria dos isolados (56\%) foi resistente a pelo menos um antimicrobiano. Alta frequência de resistência foi observada para penicilina (35,5\%) e tetraciclina (29,1\%). Todas as estirpes foram sensiveis à cefoxitina, cloranfenicol, ciprofloxacina, eritromicina e gentamicina. Todos os isolados foram negativos para o gene mecA. O presente trabalho sugere que jabutis saudáveis são colonizados principalmente por CoNS, especialmente S. sciuri. Metade dos isolados foram resistentes a pelo menos um antimicrobiano, levantando questões sobre o possivel papel desses animais como reservatórios de genes de resistência aos antimicrobianos.

Palavras-chave: répteis, estafilococos coagulase-negativos, S. sciuri, S. xylosus, Chelonoidis carbonaria.

\section{INTRODUCTION}

In the last few decades, there has been a global increase in the adoption of reptiles as companion animals. According to data issued by the latest census of companion animals, Brazil has the ninth largest population of reptiles in the world (IBGE, 2013). These exotic pets, especially turtles and tortoises, have gained popularity because of their appearance and complaisant nature (HOSSAIN et al., 2020). 
Despite the increasing popularity of reptiles as pets, studies have demonstrated that these animals represent a potential threat to public health (CDC, 2019; RAMOS et al., 2019). These animals can act as reservoirs and potential disseminators of pathogenic microorganisms, including Salmonella spp., pathogenic Escherichia coli, and Leptospira spp., and can also contribute to the spread of antimicrobial resistance genes (EBANI, 2017; RAMOS et al., 2019).

Staphylococcus spp. are important commensal bacteria, which can cause a wide variety of diseases in both humans and animals, including nosocomial infections (WIELER et al., 2011; WALTHER et al., 2017). The genus is divided into two groups according to production of the coagulase enzyme: coagulase-positive staphylococci (CoPS) and coagulase-negative staphylococci (CoNS). CoPS are responsible for most infections, whereas CoNS represent most commensal staphylococci from different hosts and are involved in infections in a variety of species, including humans (DIMITRIOU et al., 2011; WALLER et al., 2011; BIEROWIEC et al., 2019). In addition to this pathogenic potential, CoNS have the ability to acquire, harbor, and transfer resistance genes to other staphylococci, and even to other bacterial species (OTTO, 2013; BECKER et al., 2014).

Over the years, CoPS and CoNS have been extensively investigated in humans and domestic animals but few studies have been performed in wildlife. There are reports of the colonization and antimicrobial resistance of staphylococci isolated from some wild mammals, birds, and even amphibians (SLAUGHTER et al., 2001; MAMA et al., 2019; RUIZ-RIPA et al., 2020). However, there are limited studies on staphylococci isolated from healthy reptiles, and most of these did not evaluate the antimicrobial resistance of the isolates (TADDEI et al., 2010; DI IANNI et al., 2015; ORIÁ et al., 2015; CARDOSO-BRITO et al., 2019).

Given the notable lack of data on the carriage and antimicrobial resistance profile of potentially pathogenic staphylococci in pet reptiles, this research evaluated the frequency, distribution, and antimicrobial-susceptibility patterns of staphylococcal species isolated from healthy tortoises in Brazil.

\section{MATERIALS AND METHODS}

\section{Samples}

A convenience sampling of 66 apparently healthy tortoises (Chelonoidis carbonaria) was conducted over a 12-month period (February 2019 to February 2020). Samples were collected by the veterinary staff of the Wild Animals Screening Center (CETAS) in Belo Horizonte city (Minas Gerais, Brazil), an agency responsible for receiving, rehabilitating, and reintroducing wild animals into their natural environment. The tortoises sampled in this research arrived at the center through voluntary delivery, rescue, or apprehension by surveillance agencies. For sampling procedures, a sterile swab (Cral; Cotia, SP, Brazil) was introduced 5-6 cm into the cloaca and rotated five times, as described by IVES et al. (2017). The swab was placed in a sterile microtube, stored in a transport box with ice packs, and transported to the Bacteriosis and Research Laboratory of the Veterinary School of the Federal University of Minas Gerais (UFMG) for immediate processing. The study was approved by the Ethical Committee on Animal Use (CEUA) of UFMG under protocol 238/2015 and by Instituto Chico Mendes de Conservação da Biodiversidade (ICMBio) under protocol 49195-1.

\section{Staphylococcus sp. isolation and identification}

For Staphylococcus sp. isolation, swabs were plated onto Mannitol salt agar (Difco, USA) and incubated at $37^{\circ} \mathrm{C}$ for $24 \mathrm{~h}$. Morphologically suggestive colonies were isolated on Brain Heart Infusion agar (BHI) (Difco, USA) and identified by matrix-assisted laser desorption/ionization - time of flight mass spectrometry (MALDI-TOF MS; Bruker Daltonics, Bremen, Germany) using the standard extraction protocol recommended by Bruker (MATSUDA et al., 2012).

\section{Antimicrobial susceptibility and mecA detection}

Antimicrobial susceptibility tests were performed using disk diffusion in agar, according to the Clinical and Laboratory Standards Institute (CLSI) documents M100-S30 (CLSI, 2020) and VET08 (CLSI, 2018). The following antimicrobials were tested: cefoxitin $(30 \mu \mathrm{g})$, penicillin (10 units), tetracycline $(30 \mu \mathrm{g})$, trimethoprim/sulfamethoxazole $(25 \mu \mathrm{g})$, chloramphenicol $(30 \mu \mathrm{g})$, erythromycin (15 $\mu \mathrm{g})$, clindamycin $(2 \mu \mathrm{g})$, gentamicin $(10 \mu \mathrm{g})$, and ciprofloxacin $(5 \mu \mathrm{g})$ (DME, BRA). Staphylococcus aureus ATCC 25923 was used as a control strain. Additionally, DNA extraction was performed, according to PITCHER, et al. (1989), and methicillinresistant staphylococci (MRS) were investigated by detection of the mecA gene, as previously described by MURAKAMI et al. (1991).

\section{Statistical analysis}

The association between phenotypic resistance and staphylococcal species was evaluated 
by chi-square or Fisher's exact tests, using GraphPad Prism v.8 (GraphPad Software, San Diego, CA, USA). Differences were considered significant at $\mathrm{P}<0.05$.

\section{RESULTS}

In this study, 48 out of $66(72.7 \%)$ tested tortoises were positive for staphylococcal species (Table 1). All isolates were CoNS and four different species were detected, with S. sciuri $(81.3 \%)$ isolated significantly more frequently than the other species (Table 1) $(\mathrm{P}<0.001)$. The frequency of $S$. xylosus was also significantly different from that of $S$. kloosii and S. saprophyticus $(\mathrm{P}=0.048)$.

Twenty-seven $(56.2 \%)$ isolates were resistant to at least one antimicrobial agent, while twenty-one $(43.8 \%)$ were susceptible to all tested antimicrobials. There was a high frequency of resistance to penicillin $\mathrm{G}(35.5 \%)$, followed by tetracycline $(29.1 \%)$, clindamycin $(2 \%)$, and trimethoprim/sulfamethoxazole $(2 \%)(\mathrm{P}<0.05)$. Resistance to penicillin G(CLI/SUT: $P<0.001$; others: $\mathrm{P}<0.001)$ and tetracycline (CLI/SUT: $\mathrm{P}=0.0004$; Others: $\mathrm{P}<0.001)$ was significantly greater than that of the other tested antimicrobial agents. However, no significant differences were reported in resistance between penicillin $G$ and tetracycline. All isolates were susceptible to cefoxitin, chloramphenicol, erythromycin, gentamicin, and ciprofloxacin.

Table 1 presents the antimicrobial resistance phenotypes of staphylococcal species recovered from healthy tortoises in Brazil. Staphylococcus sciuri presented resistance to penicillin $\mathrm{G}$, tetracycline, and clindamycin. S. xylosus and S. kloosii presented resistance to penicillin $\mathrm{G}$ and tetracycline and $S$. saprophyticus presented resistance to tetracycline and trimethoprim-sulfamethoxazole. All four recovered staphylococcal species had isolates resistant to tetracycline, and all presented isolates with resistance to more than one antimicrobial agent (co-resistance). All isolates were negative for the mec $A$ gene.

\section{DISCUSSION}

Despite the clear increase in the adoption of reptiles as pets, including tortoises, few studies have focused on the role of these species as a reservoir of bacterial pathogens. To the best of our knowledge, this is the first study to isolate staphylococci from healthy reptiles and investigate their antimicrobial susceptibility. Notably, the incidence of staphylococci in tortoises $(72.7 \%)$ was similar to that in wild birds (60-75\%) and wild mammals (37.7-90.8\%) (CHEN et al., 2016; SOUSA et al., 2016; MAMA et al., 2019; RUIZ-RIPA et al., 2020). These results suggested that staphylococci are commensals of the mucous membrane in tortoises, which is similar to previous observations in mammals and birds (NAGASE et al., 2002; SOUSA et al., 2016; RUIZ-RIPA et al., 2020).

All isolates in the present study were identified as CoNS (Table 1). There are limited data on the factors that influence colonization by CoNS. Recently, GARCÍA et al. (2020) suggested that CoPS colonization seems to be more frequent in carnivores, raising the hypothesis of an influence of diet on staphylococcal colonization in animals. Interestingly, tortoises are fed with non-meat-based diets, which could justify the presence of CoNS instead of CoPS isolates.

Staphylococcus sciuri was the predominant species recovered from the sample tortoises, accounting for more than $80 \%$ of the isolates (Table 1 ).

Table 1 - Frequency, distribution, and antimicrobial resistance phenotypes of staphylococcal species recovered from healthy tortoises (n =66) in Minas Gerais, Brazil.

\begin{tabular}{|c|c|c|c|c|c|c|c|c|c|c|}
\hline Species & $\mathrm{n}(\%)^{*}$ & PEN & TET & CLI & SXT & CEF & ERY & GEN & CIP & CLO \\
\hline S. sciuri & $39(81.3)^{\mathrm{a}}$ & 13 & 10 & 1 & 0 & 0 & 0 & 0 & 0 & 0 \\
\hline S. xylosus & $6(12.5)^{b}$ & 2 & 2 & 0 & 0 & 0 & 0 & 0 & 0 & 0 \\
\hline S. kloosii & $2(4.2)^{c}$ & 2 & 1 & 0 & 0 & 0 & 0 & 0 & 0 & 0 \\
\hline S. saprophyticus & $1(2)^{\mathrm{c}}$ & 0 & 1 & 0 & 1 & 0 & 0 & 0 & 0 & 0 \\
\hline Total & $\begin{array}{c}48 \\
(100 \%)\end{array}$ & $\begin{array}{c}17 \\
(35.5 \%)\end{array}$ & $\begin{array}{c}14 \\
(29.1 \%)\end{array}$ & $\begin{array}{c}1 \\
(2 \%)\end{array}$ & $\begin{array}{c}1 \\
(2 \%)\end{array}$ & $\begin{array}{c}0 \\
(0 \%)\end{array}$ & $\begin{array}{c}0 \\
(0 \%)\end{array}$ & $\begin{array}{c}0 \\
(0 \%)\end{array}$ & $\begin{array}{c}0 \\
(0 \%)\end{array}$ & $\begin{array}{c}0 \\
(0 \%)\end{array}$ \\
\hline
\end{tabular}

*Multiple comparison: different letters indicate significant differences.

PEN, penicillin G; TET, tetracycline; CLI, clindamycin; SXT, trimethoprim-sulfamethoxazole; CEF, cefoxitin; ERY, erythromycin; GEN, gentamicin; CIP, ciprofloxacin; CLO, chloramphenicol. 
This result was not surprising, as $S$. sciuri is the most common CoNS isolate in other healthy wild animals, including birds, boars, hedgehogs, red foxes, rabbits, badgers, and other mammals (SOUSA et al., 2016; MAMA et al., 2019; GARCÍA et al., 2020; RUIZ-RIPA et al., 2020). Furthermore, this bacterium is known to have a wide range of hosts, is adapted to different habitats (NEMEGHAIRE et al., 2014; GÓMEZ et al., 2017; SCHOENFELDER et al., 2017; RUIZRIPA et al., 2020), and has also been reported as the causative agent of occasional, but serious, infections in humans, including endocarditis, peritonitis, urinary tract infections, and septicemia (STEPANOVIĆ et al., 2002; STEPANOVIĆ et al., 2005; SEVERIN et al., 2010). In this context, it is important to remember that bilateral transmission of commensal staphylococci between pets and their owners has been widely reported (BAPTISTE et al., 2005; WEESE et al., 2006; HANSELMAN et al., 2009).

Staphylococcus xylosus, S. kloosii, and S. saprophyticus were also isolated in the present study; although, at a much lower frequency than $S$. sciuri (Table 1). These species are less pathogenic but opportunistic microorganisms, as are most CoNS (BECKER et al., 2014), and have been reported to colonize and cause infection in humans and some wild and domestic animals (SLAUGHTER et al., 2001; PEER et al., 2011; GIORDANO et al., 2016; SREDNIK et al., 2017). Specifically, $S$. saprophyticus is the second highest cause of urinary tract infections in women and is typically classified as a human colonizer (LATHAM et al., 1983; VON EIFF et al., 2002; RAZ et al., 2005; FARIÑA et al., 2013). Unfortunately, it is unclear if an anthropogenic activity and/or human contact, including manipulation of these animals, have had influenced the isolation rate of S. saprophyticus in the present study.

It is important to highlight that CoNS, including $S$. sciuri, are known for their capacity to carry and disseminate antimicrobial resistance determinants (SCHOENFELDER et al., 2017), which contribute to their pathogenic potential (STEPANOVIĆ et al., 2002; FREY et al., 2013; BEIMS et al., 2016). In the present study, more than half of the isolates were resistant to at least one tested antimicrobial agent, mostly penicillin $\mathrm{G}(35.5 \%)$ and tetracycline (29.1\%) (Table 2), which are widely used in human and veterinary medicine. Unfortunately, the antimicrobial history of the sampled animals was unknown, but neither penicillin nor tetracycline are listed as common antimicrobials to treat bacterial infections in tortoises (MAUTINO \& PAGE, 1993). In fact, the isolates were fully susceptible to most compounds recommended for these animals, including gentamicin, chloramphenicol, ciprofloxacin, and trimethoprim-sulfonamide.

Among the $S$. sciuri isolates, resistance to penicillin $\mathrm{G}$ and tetracycline $(33.3 \%$ and $25.6 \%$, respectively) was more common than resistance to the other antimicrobials tested. These rates were much lower than those reported by NEMEGHAIRE et al. (2014) (98.6\% and 60\%, respectively) and SCHOENFELDER et al. (2017) (74\% and $87 \%$, respectively) for $S$. sciuri isolates from farm animals. This result was expected since the selective pressure of antimicrobials is likely much lower in tortoises than that in livestock. The source of the resistance to penicillin and tetracycline in these animals is unknown, but both antimicrobials have moderate potential for bioaccumulation in plants (TASHO \& CHO, 2016), which is the main food source for many animals, including captive and free-living tortoises.

Over the last decade, MRS have emerged, creating concern for human and veterinary health. Resistance to all beta-lactam antimicrobials as a consequence of the acquisition of the mecA gene excludes practically all of the first-choice treatment options for both animals and humans, drastically reducing therapeutic alternatives (MARIN, 2002). There are several reports on the colonization and infection of companion animals that transmit MRS

Table 2 - Antimicrobial resistance phenotypes of Staphylococcus species recovered from tortoises in Brazil.

\begin{tabular}{lccc}
\hline Species & Total of isolates & Antimicrobial resistance phenotype & Co-resistance \\
\hline S. sciuri & 39 & PEN $^{13}$, TET $^{10}$, CLI $^{1}$ & PEN-TET $^{2}$ PEN-CLI $^{1}$ \\
S. xylosus & 6 & PEN $^{1}$ TET $^{2}$ & PEN-TET $^{1}$ \\
S. kloosii & 2 & PEN $^{2}$ TET $^{1}$ & PEN-TET $^{1}$ \\
S. saprophyticus & 1 & TET $^{1} ;$ SXT $^{1}$ & TET-SXT $^{1}$ \\
\hline
\end{tabular}

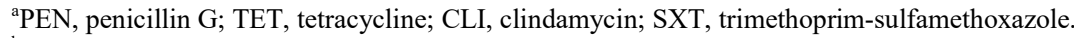

${ }^{\mathrm{b}} \mathrm{Superscript}$ numbers indicate the number of isolates with the same characteristic. 
strains (VAN DUIJKEREN et al., 2011; POMBA et al., 2017), showing the relevance of studies monitoring the occurrence of MRS in animals. Fortunately, there were no MRS isolates in the tortoises evaluated in this study. Although, previous studies have suggested that biofilms also play a role in the treatment resistance of staphylococci infection, information on biofilm production in CoNS isolated from wild animals is lacking (Lee et al., 2019). Thus, future studies should also evaluate the capacity of biofilm formation in these CoNS isolates from tortoises.

This study has some limitations. Due to the small number of sampled animals, further studies are needed to determine the prevalence of staphylococci and the most common species in tortoises. Additionally, other reptile species should be studied to better understand the prevalence of staphylococci in these animals, as well as to clarify their role as reservoirs of drug-resistant staphylococci.

\section{CONCLUSION}

In conclusion, the present research suggested that healthy tortoises are mainly colonized by CoNS, especially $S$. sciuri. Staphylococci from tortoises seem to be susceptible to the majority of antimicrobial classes tested, but more than half of the isolates were resistant to at least one antimicrobial, penicillin or tetracycline, both of which are widely used in veterinary medicine. This is the first study to evaluate the colonization and antimicrobial resistance profile of staphylococci isolated from the cloacae of healthy tortoises, as well as from healthy reptiles.

\section{ACKNOWLEDGMENTS}

We thank CETAS-BH for support and animal samples. This study was financed in part by the Coordenação de Aperfeiçoamento de Pessoal de Nível Superior - Brasil (CAPES) - Finance Code 0774/2017. We also thank, Conselho Nacional de Desenvolvimento Científico e Tecnológico (CNPq), Fundação de Amparo a Pesquisa do Estado de Minas Gerais (FAPEMIG), and $\mathrm{PRPq} / \mathrm{UFMG}$ for all the financial support.

\section{DECLARATION OF CONFLICT OF} INTEREST

The authors declare that they have no conflicts of interest.

\section{AUTHORS' CONTRIBUTIONS}

All authors contributed to the study conception and design. Material preparation and samples collection were performed by Nathalia Abreu Borges Trevizani and Angélica Maria Araújo Souza. Laboratory analysis were performed by
Jordana Almeida Santana and Brendhal Almeida Silva. The first draft of the manuscript was written by Jordana Almeida Santana and Rodrigo Otávio Silveira Silva. All authors read and approved the final manuscript.

\section{BIOETHICS AND BIOSSECURITY COMMITTEE APPROVAL}

This study was approved by the Ethical Committee on Animal Use (CEUA) of the Universidade Federal de Minas Gerais (UFMG) under protocol 238/2015 and by the Instituto Chico Mendes de Conservação da Biodiversidade (ICMBio) under protocol 49195-1.

\section{REFERENCES}

BAPTISTE, K. E. et al. Methicillin-resistant Staphylococci in Companion Animals. Emerging Infectious Diseases, v.11, p.1942-1944, 2005. Available from: <https://wwwnc.cdc.gov/ eid/article/11/12/05-0241_article>. Accessed: May, 3, 2021. doi: 10.3201/eid1112.050241.

BECKER, K. et al. G. Coagulase-negative staphylococci. Clinical Microbiology Reviews, v.27, p.870-926, 2014. Available from: $<$ https://cmr.asm.org/content/27/4/870>. Accessed: May, 3, 2021. doi: 10.1128/CMR.00109-13.

BEIMS, H. et al. Isolation of Staphylococcus sciuri from horse skin infection. Open Veterinary Journal, v.6, p.242-246, 2016. Available from: <https://www.ajol.info//index.php/ovj/article/ view/150066>. Accessed: May, 3, 2021. doi: 10.4314/ovj.v6i3.14.

BIEROWIEC, K. et al. Prevalence of Staphylococcus species colonization in healthy and sick cats. BioMed Research International, v.2019, p.4360525, 2019. Available from: <https:// www.hindawi.com/journals/bmri/2019/4360525/>. Accessed: May, 3, 2021. doi: 10.1155/2019/4360525.

CARDOSO-BRITO, V. et al. Conjunctival bacterial flora and antimicrobial susceptibility of captive and free-living sea turtles in Brazil. Veterinary Ophthalmology, v.22, p.246-255, 2019. Available from: <https://onlinelibrary.wiley.com/doi/abs/10.1111/ vop.12584>. Accessed: May, 3, 2021. doi: https://doi.org/10.1111/ vop. 12584 .

CENTER FOR DISEASE CONTROL AND PREVENTION (CDC). Reptiles and amphibians/Healthy pets, healthy people, 2019. Available from: <https://www.cdc.gov/healthypets/pets/ reptiles.html>. Accessed: Nov. 26, 2020.

CHEN, M. M. S. et al. Methicillin resistance gene diversity in staphylococci isolated from captive and free-ranging wallabies. Infection Ecology \& Epidemiology, v.5, 2016. Available from: $<$ https://www.tandfonline.com/doi/full/10.3402/iee.v6.31507>. Accessed: May, 3, 2021. doi: 10.3402/iee.v6.31507.

DI IANNI, F. et al. Conjunctival flora of clinically normal and diseased turtles and tortoises. BMC veterinary research, v.11, p.91, 2015. Available from: <https://bmcvetres.biomedcentral. com/articles/10.1186/s12917-015-0405-x>. Accessed: May, 3, 2021. doi: 10.1186/s12917-015-0405-x.

DIMITRIOU, G. et al. Clinical and microbiological profile of persistent coagulase-negative staphylococcal bacteraemia in neonates. Clinical Microbiology and Infection, v.17, p.1684- 
1690, 2011. Available from: <https://linkinghub.elsevier.com/ retrieve/pii/S1198743X1461898X>. Accessed: May, 3, 2021. doi: 10.1111/j.1469-0691.2011.03489.x.

EBANI, V. V. Domestic reptiles as source of zoonotic bacteria: A mini review. Asian Pacific Journal of Tropical Medicine, v.10, p.723-728, 2017. Available from: <https:/www.sciencedirect. com/science/article/pii/S1995764517305035>. Accessed: May, 3, 2021. doi: 10.1016/j.apjtm.2017.07.020.

FARIÑA, N. et al. Clinically significant coagulase-negative staphylococci: Most frequent species and virulence factors. Revista Chilena de Infectología, v.30, p.480-488, 2013. Available from: $<$ https://scielo.conicyt.cl/scielo.php?script $=$ sci arttext\&pid $=$ S0716-10182013000500003\&lng=en\&nrm $=$ is o\&tlng=en>. Accessed: May, 3, 2021. doi: 10.4067/S071610182013000500003 .

FREY, Y. et al. Genetic characterization of antimicrobial resistance in coagulase-negative staphylococci from bovine mastitis milk. Journal of Dairy Science, v.96, p.2247-2257, 2013. Available from: $\quad<$ https://www.journalofdairyscience.org/article/S00220302(13)00122-7/fulltext>. Accessed: May, 3, 2021. doi: 10.3168/ jds.2012-6091.

GARCÍA, L. A. et al. Staphylococcus Spp. from wild mammals in aragón (spain): antibiotic resistance status. Journal of Veterinary Research, v.64, p.373-379, 2020. Available from: <https://www. ncbi.nlm.nih.gov/pmc/articles/PMC7497752/pdf/jvetres-64-373. pdf $>$. Accessed: May, 3, 2021. doi: 10.2478/jvetres-2020-0057.

GIORDANO, N. et al. Erythema nodosum associated with Staphylococcus xylosus septicemia. Journal of Microbiology, Immunology and Infection, v.49, p.134-137, 2016. Available from: $\quad<$ https://www.sciencedirect.com/science/article/pii/ S1684118212002150?via\%3Dihub>. Accessed: May, 3, 2021. doi: 10.1016/j.jmii.2012.10.003.

GÓMEZ, P. et al. Diversity of species and antimicrobial resistance determinants of staphylococci in superficial waters in Spain. FEMS microbiology ecology, v.93, 2017. Available from: $<$ https://academic.oup.com/femsec/article/93/1/fiw208/2666408>. Accessed: May, 3, 2021. doi: 10.1093/femsec/fiw208.

HANSELMAN, B. A. et al. Coagulase positive staphylococcal colonization of humans and their household pets. The Canadian Veterinary Journal, v.50, p.954-958, 2009. Available from: $<$ https://www.ncbi.nlm.nih.gov/pmc/articles/PMC2726022/>. Accessed: May, 3, 2021.

HOSSAIN, S. et al. Phylogenetic relationships, virulence and antimicrobial resistance properties of Klebsiella sp. isolated from pet turtles in Korea. Letters in Applied Microbiology, v.70, p.7178, 2020. Available from: <https://sfamjournals.onlinelibrary. wiley.com/doi/abs/10.1111/lam.13245>. Accessed: May, 3, 2021. doi: 10.1111/lam.13245.

INSTITUTO BRASILEIRO DE GEOGRAFIA E ESTATÍSTICA (IBGE). População de animais de estimação no Brasil (ABINPET), 2013. Available from: <https://www.gov.br/agricultura/pt-br/assuntos/ camaras-setoriais-tematicas/documentos/camaras-tematicas/insumosagropecuarios/anos-anteriores/ibge-populacao-de-animais-de-estimacaono-brasil-2013-abinpet-79.pdf/view>. Accessed: Nov. 26, 2020.

IVES, A. K. et al. Detection of Salmonella enterica Serovar Montevideo and Newport in Free-ranging sea turtles and beach sand in the Caribbean and persistence in sand and seawater microcosms. Zoonoses and Public Health, v.64, p.450-459, 2017. Available from: <https://onlinelibrary.wiley.com/doi/abs/10.1111/ zph.12324>. Accessed: May, 3, 2021. doi: 10.1111/zph.12324.

LATHAM, R. H.et al. Urinary tract infections in young adult women caused by Staphylococcus saprophyticus. JAMA, v.250, p.3063-3066, 1983. Available from: <https://pubmed.ncbi.nlm. nih.gov/6644988/>. Accessed: May, 3, 2021.

LEE, S. et al. Biofilm production of coagulase-negative staphylococci isolated from rescued wild animals in the Republic of Korea. Acta Veterinaria Scandinavica, v.61, p.50, 2019. Available from: <https:/www.ncbi.nlm.nih.gov/pmc/articles/ PMC6814046/>. Accessed: Jun. 6, 2021. doi: 10.1186/s13028019-0485-x.

MAMA, O. M. et al. High diversity of coagulase negative staphylococcispecies in wild boars, with low antimicrobial resistance rates but detection of relevant resistance genes. Comparative Immunology, Microbiology and Infectious Diseases, v.64, p.125-129, 2019. Available from: <https://www.sciencedirect. com/science/article/abs/pii/S0147957119300517?via\%3Dihub>. Accessed: May, 3, 2021. doi: 10.1016/j.cimid.2019.03.006.

MARIN, M. Methicillin resistant Staphylococcus. Medicina, v.62 Suppl 2, p.30-35, 2002. Available from: <https://pubmed.ncbi. nlm.nih.gov/12481486/>. Accessed: May, 3, 2021.

MATSUDA, N.; et al.,. Evaluation of a simple protein extraction method for species identification of clinically relevant staphylococci by matrix-assisted laser desorption ionization - Time of flight mass spectrometry. Journal of Clinical Microbiology, v.50, p.3862-3866, 2012. Available from: <https://www.ncbi.nlm. nih.gov/pmc/articles/PMC3502947/>. Accessed: May, 3, 2021. doi: 10.1128/JCM.01512-12.

MAUTINO, M.; PAGE, C. D. biology and medicine of turtles and tortoises. Veterinary Clinics of North America: Small Animal Practice, v.23, p.1251-1270, 1993. Available from: $<$ https://www.sciencedirect.com/science/article/abs/pii/ S0195561693501547?via\%3Dihub>. Accessed: May, 3, 2021. doi: 10.1016/S0195-5616(93)50154-7.

MURAKAMI, K. et al. Identification of methicillin-resistant strains of staphylococci by polymerase chain reaction. Journal of Clinical Microbiology, v.29, p.2240-2244, 1991. Available from: $<\mathrm{https}$ ://jcm.asm.org/content/29/10/2240>. Accessed: May, 3, 2021. doi: 10.1128/JCM.29.10.2240-2244.1991.

NAGASE, N. et al. Isolation and species distribution of Staphylococci from animal and human skin. Journal of Veterinary Medical Science, v.64, p.245-250, 2002. Available from: $<$ https:// www.jstage.jst.go.jp/article/jvms/64/3/64_3_245/_article $>$. Accessed: May, 3, 2021. doi: 10.1292/jvms.64.245.

NEMEGHAIRE, S. et al. Characterization of methicillin-resistant Staphylococcus sciuri isolates from industrially raised pigs, cattle and broiler chickens. Journal of Antimicrobial Chemotherapy, v.69, p.2928-2934, 2014. Available from: <https://academic.oup. com/jac/article/69/11/2928/2911253>. Accessed: May, 3, 2021. doi: $10.1093 / \mathrm{jac} / \mathrm{dku} 268$.

ORIÁ, A. P. et al. Ophthalmic diagnostic tests in captive redfooted tortoises (Chelonoidis carbonaria) in Salvador, northeast Brazil. Veterinary Ophthalmology, v.18 Suppl 1, p.46-52, 2015. 
Available from: <https://onlinelibrary.wiley.com/doi/abs/10.1111/ vop.12175>. Accessed: May, 3, 2021. doi: 10.1111/vop.12175.

OTTO, M. Coagulase-negative staphylococci as reservoirs of genes facilitating MRSA infection: Staphylococcal commensal species such as Staphylococcus epidermidis are being recognized as important sources of genes promoting MRSA colonization and virulence. BioEssays: News and Reviews in Molecular, Cellular and Developmental Biology, v.35, p.4-11, 2013. Available from: $<$ https://onlinelibrary.wiley.com/doi/full/10.1002/ bies.201200112>. Accessed: May, 3, 2021. doi: 10.1002/ bies. 201200112

PEER, M. A. et al. Sepsis due to linezolid resistant Staphylococcus cohnii and Staphylococcus kloosii: first reports of linezolid resistance in coagulase negative staphylococci from India. Indian Journal of Medical Microbiology, v.29, p.60-62, 2011. Available from: <https://pubmed.ncbi.nlm.nih.gov/21304198/>. Accessed: May, 3, 2021. doi: 10.4103/0255-0857.76527.

PITCHER, D. G. et al. Rapid extraction of bacterial genomic DNA with guanidium thiocyanate. Letters in Applied Microbiology, v.8, p.151-156, 1989. Available from: <https://sfamjournals. onlinelibrary.wiley.com/doi/abs/10.1111/j.1472-765X.1989. tb00262.x>. Accessed: May 3, 2021. doi: 10.1111/j.1472765X.1989.tb00262.x

POMBA, C. et al. Public health risk of antimicrobial resistance transfer from companion animals. Journal of Antimicrobial Chemotherapy, v.72, p.957-968, 2017. Available from: <https:// academic.oup.com/jac/article/72/4/957/2629141>. Accessed: May, 3, 2021. doi: $10.1093 / \mathrm{jac} / \mathrm{dkw} 481$.

RAMOS, C. P. et al. Identification and characterization of Escherichia coli, Salmonella Spp., Clostridium perfringens, and C. difficile isolates from reptiles in Brazil. BioMed Research International, v.2019, p.1-9, 2019. Available from: $<$ https://www. hindawi.com/journals/bmri/2019/9530732/>. Accessed: May, 3, 2021. doi: $10.1155 / 2019 / 9530732$.

RAZ, R. et al. Who are you-Staphylococcus saprophyticus? Clinical Infectious Diseases, v.40, p.896-898, 2005. Available from: <https://academic.oup.com/cid/article/40/6/896/347623>. Accessed: May, 3, 2021. doi: 10.1086/428353.

RUIZ-RIPA, L. et al. Frequency and characterization of antimicrobial Resistance and Virulence Genes of CoagulaseNegative Staphylococci from Wild Birds in Spain. Detection of tst-Carrying $S$. sciuri Isolates. Microorganisms, v.8, p.1317, 2020. Available from: <https://www.mdpi.com/20762607/8/9/1317>. Accessed: May, 3, 2021. doi: 10.3390/ microorganisms 8091317 .

SCHOENFELDER, S. M. K. et al. Antibiotic resistance profiles of coagulase-negative staphylococci in livestock environments. Veterinary Microbiology, SI: Antimicrobial Resistance. v.200, p.79-87, 2017. Available from: https://www.sciencedirect.com/ science/article/pii/S037811351630102X?via\%3Dihub. Accessed: May 3, 2021. doi: 10.1016/j.vetmic.2016.04.019.

SEVERIN, J. A. et al. Nasal carriage of Methicillin-Resistant and Methicillin-Sensitive Strains of Staphylococcus sciuri in the Indonesian Population. Antimicrobial Agents and Chemotherapy, v.54, p.5413-5417, 2010. Available from: $<$ https://aac.asm.org/content/54/12/5413>. Accessed: May, 3, 2021. doi: 10.1128/AAC.00426-10.
SLAUGHTER, D. M. et al. Antibiotic resistance in coagulasenegative staphylococci isolated from Cope's gray treefrogs (Hyla chrysoscelis). FEMS Microbiology Letters, v.205, p.265-270, 2001. Available from: <https://academic.oup.com/femsle/ article/205/2/265/521016>. Accessed: May, 3, 2021. doi: 10.1111/ j.1574-6968.2001.tb10959.x.

SOUSA, M. et al. Genetic diversity and antibiotic resistance among coagulase-negative staphylococci recovered from birds of prey in Portugal. Microbial Drug Resistance, v.22, p.727-730, 2016. Available from: <https://www.liebertpub.com/doi/10.1089/ mdr.2015.0266>. Accessed: May, 3, 2021. doi: 10.1089/ mdr.2015.0266.

SREDNIK, M. E. et al. Detection of a mecC-positive Staphylococcus saprophyticus from bovine mastitis in Argentina. Journal of Global Antimicrobial Resistance, v.10, p.261-263, 2017. Available from: <https://www.sciencedirect.com/science/ article/abs/pii/S2213716517301030?via\%3Dihub>. Accessed: May, 3, 2021. doi: 10.1016/j.jgar.2017.05.016.

STEPANOVIĆ, S. et al. Surgical wound Infection associated with Staphylococcus sciuri. Scandinavian Journal of Infectious Diseases, v.34, p.685-686, 2002. Available from: <https:// www.tandfonline.com/doi/abs/10.1080/00365540110076949a>. Accessed: May, 3, 2021. doi: 10.1080/00365540110076949a.

STEPANOVIĆ, S. et al. Identification and characterization of clinical isolates of members of the Staphylococcus sciuri Group. Journal of Clinical Microbiology, v.43, p.956-958, 2005. Available from: <https://jcm.asm.org/content/43/2/956> Accessed: May, 3, 2021. doi: 10.1128/JCM.43.2.956-958.2005.

TADDEI, S. et al. Conjunctival flora of clinically normal captive green iguanas (Iguana iguana). Veterinary Record, v.167, p.2930, 2010. Available from: <https://bvajournals.onlinelibrary.wiley. com/doi/abs/10.1136/vr.b4868>. Accessed: May, 3, 2021. doi: 10.1136/vr.b4868.

TASHO, R. P.; CHO, J. Y. Veterinary antibiotics in animal waste, its distribution in soil and uptake by plants: A review. The Science of the Total Environment, v.563-564, p.366-376, 2016. Available from: $\quad<$ https://www.sciencedirect.com/science/article/abs/pii/ S0048969716308427?via\%3Dihub>. Accessed: May, 3, 2021. doi: 10.1016/j.scitotenv.2016.04.140.

VAN DUIJKEREN, E. et al. Transmission of methicillin-resistant Staphylococcus pseudintermedius between infected dogs and cats and contact pets, humans and the environment in households and veterinary clinics. Veterinary Microbiology, v.150, p.338-343, 2011. Available from: <https://www.sciencedirect.com/science/ article/pii/S0378113511000770?via\%3Dihub>. Accessed: May, 3, 2021. doi: 10.1016/j.vetmic.2011.02.012.

VON EIFF, C. et al. Pathogenesis of infections due to coagulasenegative staphylococci. The Lancet Infectious Diseases, v.2, p.677-685, 2002. Available from: <https://www.thelancet. com/journals/laninf/article/PIIS1473-3099(02)00438-3/fulltext>. Accessed: May, 3, 2021. doi: 10.1016/S1473-3099(02)00438-3.

WALLER, K. P. et al. CNS species and antimicrobial resistance in clinical and subclinical bovine mastitis. Veterinary Microbiology, v.152, p.112-116, 2011. Available from: $\quad<$ https://www.sciencedirect.com/science/article/pii/ S0378113511002203?via\%3Dihub>. Accessed: May, 3, 2021. doi: 10.1016/j.vetmic.2011.04.006. 
WALTHER, B. et al. Multidrug-resistant opportunistic pathogens challenging veterinary infection control. Veterinary Microbiology, v.200, p.71-78, 2017. Available from: <https:/www.sciencedirect. com/science/article/pii/S0378113516301419?via\%3Dihub>. Accessed: May, 3, 2021. doi: 10.1016/j.vetmic.2016.05.017.

WEESE, J. S. et al. Suspected transmission of methicillinresistant Staphylococcus aureus between domestic pets and humans in veterinary clinics and in the household. Veterinary Microbiology, v.115, p.148-155, 2006. Available from:
S0378113506000071?via\%3Dihub>. Accessed: May, 3, 2021. doi: 10.1016/j.vetmic.2006.01.004.

WIELER, L. H. et al. Methicillin-resistant staphylococci (MRS) and extended-spectrum beta-lactamases (ESBL)-producing Enterobacteriaceae in companion animals: nosocomial infections as one reason for the rising prevalence of these potential zoonotic pathogens in clinical samples. International journal of medical microbiology: IJMM, v.301, p.635-641, 2011. Available from: $<$ https://www. sciencedirect.com/science/article/abs/pii/S1438422111000956?via\%3Dihub>. Accessed: May, 3, 2021. doi: 10.1016/j.ijmm.2011.09.009. 